\title{
Pemberdayaan Potensi Masyarakat Melalui Pengembangan Perdagangan, Pendidikan, Sosial, dan Lingkungan Desa Gedangan Kecamatan Grogol Kabupaten Sukoharjo
}

\author{
Puspanda Hatta $^{1}$, Agus Budiarto ${ }^{2}$, Imam Prasetyo ${ }^{3}$, Putri Karimah ${ }^{4}$, \\ Abdillah Yusron ${ }^{5}$ \\ ${ }^{1}$ Pendidikan Teknik Informatika dan Komputer, Fakultas Keguruan dan Ilmu Pendidikan, \\ Universitas Sebelas Maret \\ 2,5Pendidikkan Teknik Mesin, Fakultas Keguruan dan Ilmu Pendidikan, Universitas \\ Sebelas Maret \\ ${ }^{3}$ Seni Rupa, Fakultas Seni Rupa dan Desain, Universitas Sebelas Maret \\ ${ }^{4}$ Akuntansi, Fakultas Ekonomika dan Bisnis, Universitas Sebelas Maret \\ Corresponding email: hatta.puspanda@staff.uns.ac.id
}

\begin{abstract}
Gedangan is a village located in Grogol District, Sukoharjo Regency, Central Java. In 2021, Gedangan Village will become one of the partners of the Sebelas Maret University Student Community Services Program (KKN). In this village, $\mathrm{KKN}$ activities were carried out using a hybrid system due to the pandemic. KKN is carried out through online and offline activities with the theme of empowering community potential through counselling in the fields of animal husbandry, education, social and creative industries. The work programs that have been implemented are "Literacy Lanterns", Catfish Cultivation in Buckets, composter making, educational posters, PHBS counselling, Reading Houses, and murals to attract the public. The implementation strategy includes socialization, teaching, and various trainings. With this $\mathrm{KKN}$ team work program, the people of Gedangan Village are able to optimize the local potential of the village, especially in the fields of Education, Social, and Creative Industries. This activity is supported by the village government and local communities from various backgrounds. This activity is useful for developing Gedangan Village in managing village potential and can help the community be more interested in developing Gedangan in the future.
\end{abstract}

Keywords: Gedangan Village, Community Service, Education, Social. 


\begin{abstract}
ABSTRAK
Gedangan merupakan salah satu desa yang terletak di Kecamatan Grogol, Kabupaten Sukoharjo, Jawa Tengah. Pada tahun 2021, Desa Gedangan menjadi salah satu mitra Student Community Services Programme (KKN) Universitas Sebelas Maret. Di desa ini kegiatan KKN dilaksanakan dengan sistem hybrid akibat adanya pandemi. KKN dilakukan melalui aktifitas daring dan luring dengan tema pemberdayaan potensi masyarakat melalui penyuluhan di bidang peternakan, pendidikan, sosial, dan industri kreatif. Program kerja yang telah dilaksanakan adalah "Lentera Literasi", Budidaya Lele dalam Ember, pembuatan komposter, penempelan poster edukasi, penyuluhan PHBS, Rumah Baca, dan mural untuk menarik masyarakat. Strategi pelaksanaannya meliputi sosialisasi, pengajaran, dan berbagai pelatihan. Dengan adanya program kerja tim KKN ini, masyarakat Desa Gedangan mampu mengoptimalkan potensi lokal yang dimiliki desa, khususnya pada bidang Pendidikan, Sosial, dan Industri Kreatif. Kegiatan ini didukung oleh pemerintah desa dan masyarakat setempat dari berbagai kalangan. Kegiatan ini bermanfaat untuk mengembangkan Desa Gedangan dalam pengelolaan potensi desa dan dapat membantu masyarakat lebih tertarik mengembangkan Gedangan di masa mendatang.
\end{abstract}

Kata kunci: Gedangan, KKN, Pendidikan, Sosial.

\title{
PENDAHULUAN
}

Desa Gedangan merupakan desa yang terletak di Kecamatan Grogol, Kabupaten Sukoharjo, Provinsi Jawa Tengah. Desa Gedangan sendiri memiliki RW sejumlah 6 dan RT sejumlah 44. Desa Gedangan memiliki berbagai macam potensi yang belum banyak dikembangkan oleh masyarakat di sekitarnya salah satu diantaranya adalah perdagangan. Desa Gedangan sedang merencanakan pembangunan pasar desa demi meningkatkan perekonomian masyarakat sekitar. Untuk memaksimalkan fasilitas tempat tersebut, perlu adanya sesuatu yang memikat para pedagang agar lebih memanfaatkan tempat (pasar desa) yang telah dibuat dengan meciptakan hal yang menarik seperti, membuat beberapa sudut pasar menjadi tempat yang photogenic agar banyak dikunjungi, membuat jalur jalan yang menarik dan instagramable untuk menarik pengunjung dan pedagang baru.

Potensi yang dimiliki desa ini berikutnya adalah SDM generasi muda. SDM generasi muda yang memiliki pendidikan yang baik, akan dapat memajukan desa di masa mendatang. Pendidikan juga merupakan salah satu bidang yang sangat terdampak akibat adanya pandemi Covid-19. Seperti halnya problematika yang dihadapi mayoritas pembelajaran daring selama masa pandemi(Hatta et al., 2020), generasi muda di desa ini juga sedang menghadapi kendala pembelajaran daring. Khususnya tingkat Taman Kanak-Kanak (TK) dan Sekolah Dasar (SD). Perlu diadakan kegiatan belajar non-formal, dikarenakan pada kondisi saat ini semangat belajar anak-anak sangatlah penting. 
Selain potensi, terdapat permasalahan yang ditemukan pada saat pelaksanaan KKN. Salah satu permasalahan yang ditemukan di Desa Gedangan adalah kebersihan lingkungan. Desa ini memiliki sungai yang sedang dalam tahap revitalisasi. Dengan kondisi tersebut, perlu diadakan penyuluhan Perilaku Hidup Bersih dan Sehat (PHBS). Kebersihan lingkungan merupakan salah 1 aspek yang harus diperhatikan pada masa pandemi(Karuniawati \& Putrianti, 2020). Untuk mencegah penyebaran COVID-19 di Indonesia, Pemerintah Indonesia telah memberikan izin kepada beberapa pemerintah daerah untuk menerapkan kebijakan Pembatasan Sosial Berskala Besar (PSBB) ketimbang Karantina Wilayah menjelang akhir Maret 2020 (Setiati \& Azwar, 2020:85).

Selama masa pandemi, Satgas Covid-19 di Desa Gedangan masih menjalankan fungsi pengawasan terhadap aktifitas masyarakat di sekitar. Dengan pertimbangan itu, kegiatan KKN di Desa Gedangan ini dilaksanakan secara kombinasi luring dan daring, untuk meminimalisir kontak yang memungkinkan resiko penularan virus Covid-19. Bentuk KKN kombinasi luring dan daring bukan yang pertama kali dilakukan tim KKN dari UNS, selama masa pandemi KKN UNS dilaksanakan secara kombinasi luring dan daring sesuai status zona penularan (Djono, 2020; Estriyanto, 2020). Demi memaksimalkan potensi yang dimiliki masyarakat Desa Gedangan, KKN dilaksanakan dengan tetap memperhatikan protokol Kesehatan yang berlaku.

Dengan merujuk pada kegiatan KKN di masa Covid-19 pada periode sebelumnya, untuk menyukseskan program kerja KKN dengan metode hybrid luring dan daring, diperlukan pendekatan inovatif(Budiyanto et al., 2020). Pendekatan inovatif dilakukan dalam bentuk kegiatan-kegiatan yang belum pernah dilakukan oleh masyarakat Desa Gedangan selama pandemi. Dengan memperhatikan potensi dan permasalahan yang telah dijelaskan sebelumnya, maka kegiatan inovatif ini berfokus untuk mengatasi masalah-masalah yang ada. Adapun bentuk kegiatan yang dilakukan tim KKN ini antara lain adalah: penyuluhan perilaku hidup bersih, pemberdayaan rumah baca, upaya meningkatkan literasi melalui program lentera literasi, budidaya lele dan kangkung serta pembuatan kompos, seni mural dan penempelan poster edukasi.

\section{METODE PELAKSANAAN}

Program kerja disusun untuk dapat dilaksanan sesuai dengan keadaan masyarakat setempat. Dalam hal ini sasaran masyarakat untuk program kerja pemberdayaan potensi masyarakat melalui pengembangan perdagangan, pendidikan, sosial, dan lingkungan. adalah di Desa Gedangan Kecamatan Grogol Kabupaten Sukoharjo. Metode pelaksanakaan yang digunakan dalam menjalankan progam kerja ini adalah daring dan luring. Pelaksanakan daring dan luring dipilih karena adanya Covid 19 yang mengharuskan dilakukanya pembatasan untuk 
berkumpul dan jaga jarak sehinnga untuk efesiensi waktu maka digunakan metode pelaksanaan ini.

Survei dilakukan untuk mengetahui kondisi masyarakat sekitar, baik melaui ketua RT di Desa Gedangan Kecamatan Grogol Kabupaten Sukoharjo, untuk lebih memastikan kebutuhan masyarakaat saat ini berkatan dengan penyusunan program kerja. Sehingga program kerja yang disusun tepat sesuai sasaran kebutuhan masyarakat dalam menghadapi pandemi Covid 19. Sebelum melaksanakan beberapa program kerja, pada beberapa program kerja dilakukan studi literatur, antara lain budidaya lele dalam medium terbatas (Annisa et al., 2021), dan pembuatan komposter (Elpawati et al., 2015).

\section{HASIL DAN PEMBAHASAN}

\section{Penyuluhan PHBS}

Penyuluhan Pola Hidup Bersih dan Sehat atau PHBS ini merupakan program kerja yang berfokus pada kesehatan masyarakat setempat. Program ini dilaksanakan satu kali dalam satu periode keberjalanan KKN. Berdasarkan studi literatur, kegiatan ini dapat menjada kesehatan masyarakat, sebagai salah satu upaya pencegahan pandemi Covid-19 (Karuniawati \& Putrianti, 2020). Kegiatan ini dilaksanakan dengan cara sosialisasi kepada warga setelah adanya kegiatan senam sehat dengan tujuan agar setiap dari masyarakat mampu dan memahami bagaimana berperilaku dengan pola hidup bersih dan sehat, terlebih lagi pandemi masih ada di sekitar kita dan sangat perlu diwaspadai.

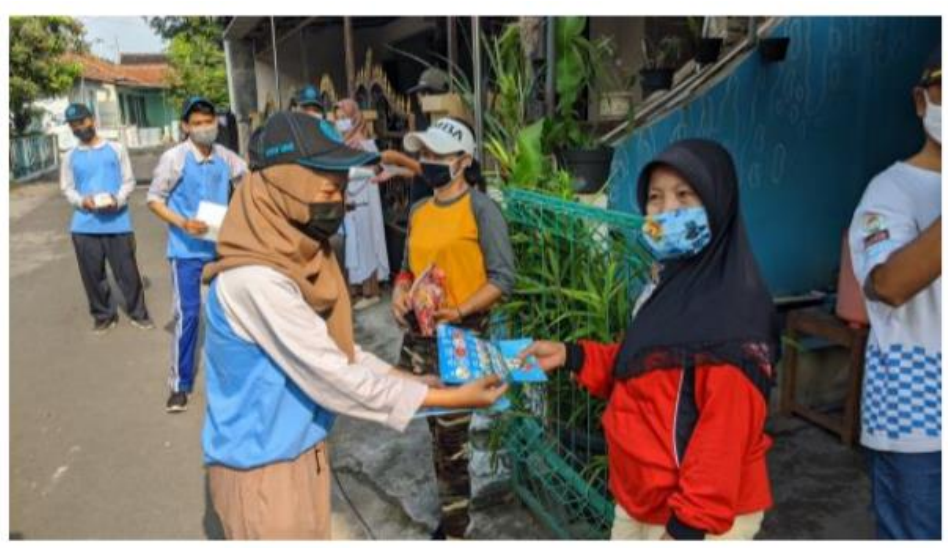

Gambar 1. Penyuluhan PHBS

Secara keseluruhan, Desa Gedangan telah memiliki kesadaran untuk menjalankan pola hidup bersih dan sehat jika dilihat dari kategori penerapan PHBS berdasarkan anjuran dari Kementerian Kesehatan RI, yaitu; lakukan persalinan di fasilitas kesehatan, memberi bayi ASI eksklusif, menimbang balita setiap bulan, dan lainnya. Kami mengundang pembicara dari Dokter Muda FK UNS, untuk melakukan sosialisasi PHBS tersebut. Selain itu, juga 
ada pencetakan poster dan selebaran agar penyuluhan ini dapat dipahami lebih maksimal oleh masyarakat setempat.

\section{Rumah Baca}

Rumah baca merupakan program dimana tim KKN 116 akan melakukan upaya revitalisasi terhadap perpustakaan desa yang berada di Balai Desa yang dimana perpustakaan tersebut merupakan area baca dan dapat digunakan oleh warga sekitar.

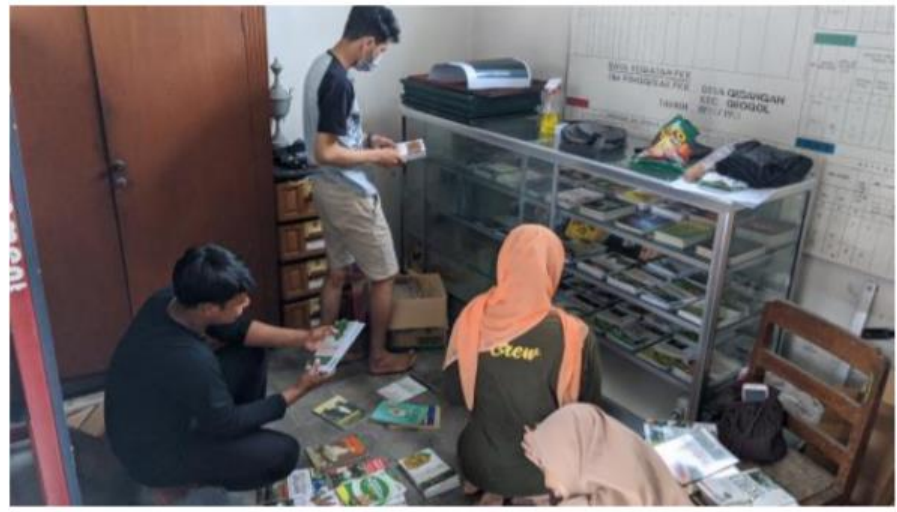

Gambar 2. Revitalisasi Ruang Baca

Program ini dilaksanakan mulai dengan menata kembali buku-buku dan inventaris bacaan yang ada sebelumnya, membersihkan ruangan, dan penempelan poster-poster untuk semangat membaca, dan diakhiri dengan inventarisasi dan pembedaan jenis buku bacaan.

\section{Budidaya Lele dan Kangkung}

Budidaya lele dan kangkung merupakan program yang harapannya dapat menjadi solusi bagi permasalahan perekonomian warga dan solusi untuk pemanfaatan lahan yang terbatas di daerah tersebut. Program ini dimulai dengan pembuatan alat budikdamber, kemudian dari alat tersebut dilanjut dengan pemasukan bibit lele ke dalam ember dan penanaman kangkung di tepian ember nya.

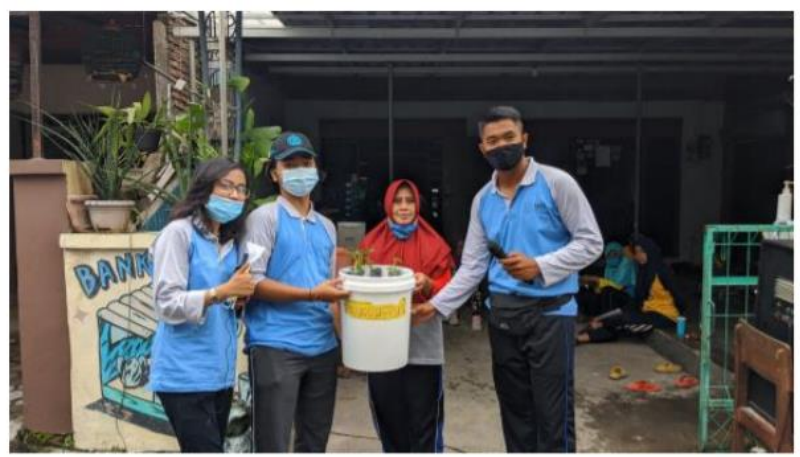

Gambar 3. Budidaya Lele dan Kangkung 
Dari hasil tersebut, kemudian oleh Tim KKN disosialisasikan kepada seluruh warga dan juga terdapat pembuatan tutorial budikdamber, agar informasi dan tutorial ini dapat dilakukan oleh masyarakat secara umum. Budikdamber yang telah dibuat, dihibahkan kepada warga agar dikembangkan.

\section{Lentera Literasi}

Lentera Literasi, merupakan program kegiatan meningkatkan literasi dan semangat belajar kepada anak-anak, khususnya kelas 1-3 SD. Program ini bekerjasama dengan pihak sekolah dasar yang ada di Desa Gedangan baik SD 01 maupun 02 Desa Gedangan. Program ini dilaksanakan secara rutin setiap hari Minggu, selama periode KKN berlangsung.

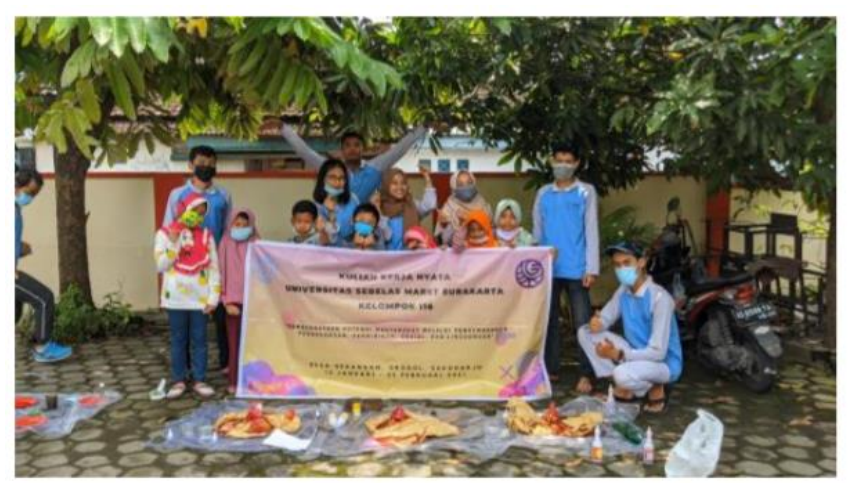

Gambar 4. Lentera Literasi

Tim KKN juga menyiapkan kurikulum belajar pada setiap pertemuan. Beberapa di antaranya adalah, kelas membuat pohon cita-cita, kelas menyanyi dan menulis, kelas pembuatan larutan pelangi dan gunung meletus, dan yang terakhir adalah kelas mewarnai. Kegiatan ini sangat disambut secara antusias oleh anak-anak SD di Desa Gedangan.

\section{Pembuatan Pupuk Kompos}

Program ini merupakan program yang tujuannya sebagai pemanfaatan limbah rumah tangga menjadi pupuk kompos yang digunakan untuk menyuburkan tanaman yang ditanam oleh para masyarakat Desa Gedangan. Program ini dilaksanakan sekali dalam satu periode KKN. Proses dalam pelaksanaannya adalah, pembuatan alat komposter terlebih dahulu yang kemudian kita meracik bahan-bahan pembuatan komposnya. Kemudian dari hasilnya didiamkan kurang lebih 2 minggu. 


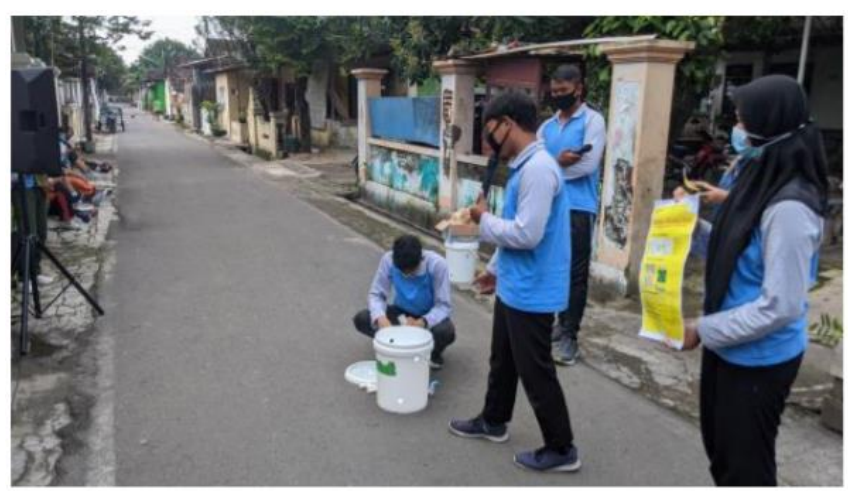

Gambar 5. Pembuatan Komposter

Hasil dari pembuatan ini, kemudian diulang caranya dalam sosialisasi mengenai pembuatan pupuk kompos kepada warga dan pemberian hasil kompos yang telah jadi sepenuhnya. Program ini dilaksanakan setelah para masyarakat melakukan agenda senam sehat setiap hari Minggu.

\section{Seni Mural}

Mural merupakan program yang dilaksanakan sebagai bentuk meningkatkan eksistensi suatu tempat, tepatnya adalah pasar desa yang akan dibangun di Desa Gedangan.

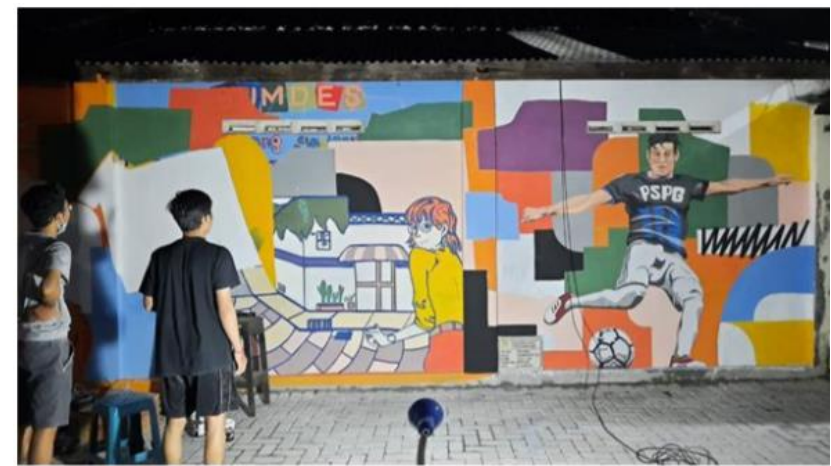

Gambar 6. Seni Mural

Hasil dari seni ini dapat digunakan sebagai spot foto yang instagramable bagi para pengunjung, baik pengunjung pasar desa ataupun penonton sepak bola karena tempatnya dekat dengan lapangan sepak bola. Program ini, dilakukan selama masa periode KKN. Dimulai dengan sketsa dan diakhiri dengan cat dan finishing.

\section{Penempelan Poster Edukasi}

Program Poster Edukasi merupakan kegiatan yang dilaksanakan oleh Tim KKN untuk menempelkan poster-poster di daerah yang strategis, agar pesan dalam poster itu dapat tersampaikan secara maksimal di kalangan masyarakat. 


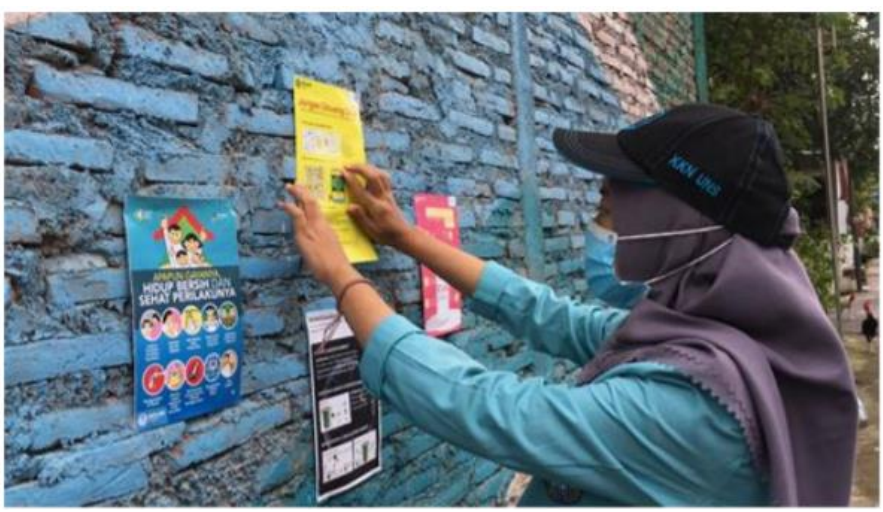

Gambar 7. Poster Edukasi

Program ini berjalan selama periode KKN berlangsung, selain penempelan di tempat yang strategis, poster tersebut juga dibagikan kepada masyarakat di masing-masing rumah. Hal ini dilakukan untuk memastikan bahwa penyebarannya dan isi dari poster tersebut dapat tersampaikan secara maksimal.

\section{KESIMPULAN}

Kegiatan KKN di lingkungan Desa Gedangan Kecamatan Grogol Kabupaten Sukoharjo selama bulan Januari-Februari 2021 telah berhasil dilaksanakan. Kegiatan ini dilakukan dengan tujuan untuk memberdayakan dan memberi edukasi kepada masyarakat tentang pemberdayaan potensi masyarakat melalui pengembangan perdagangan, pendidikan, sosial, dan lingkungan masa pandemi Covid-19. Mahasiswa KKN menyelenggarakan berbagai proker untuk mencapai tujuan tersebut mulai dari Lentera Literasi, Budidaya Lele dalam Ember, Pembuatan Komposer, Penempelan Poster Pencerdasan, Senam Sehat, Penyuluhan Nutrisi Ternak, Penyuluhan PHBS, Rumah Baca, Edukasi Melalui Media Sosial, dan Mural. Yang bertujuan untuk mengingatkan kepada masyarakat tentang pentingnya untuk tetap produktif dan tetap selalu menjaga kesehatan dan menaati protokol kesehatan. Dengan dilaksanakannya berbagai proker ini Universitas Sebelas Maret berharap agar ilmu yang telah diterapkan mahasiswa KKN kepada masyarakat dapat berguna dan bermanfaat untuk pemberdayaan masyarakat Desa Gedangan selama masa pandemi Covid-19.

\section{ACKNOWLEDGMENT}

Program KKN tematik 2021 ini dapat terlaksana dengan baik berkat dukungan dalam bentuk pendanaan dari Lembaga Penelitian dan Pengabdian Masyarakat Universitas Sebelas Maret serta kemitraan dan partisipasi yang baik oleh Desa Gedangan, Kecamatan Grogol, Kabupaten Sukoharjo, Jawa Tengah. 


\section{DAFTAR PUSTAKA}

Annisa, I. T., Deviastri, L., \& Novesar, M. R. (2021). Pelatihan dan Bimbingan Budidaya Ternak Lele Dalam Ember di Tengah Ibu Kota Jakarta. Community Engagement and Emergence Journal (CEEJ), 2(2), 200-205.

Budiyanto, C., Nikmah, N. A., Cahyaningsih, A., \& Afifah, K. (2020). Pendekatan Inovatif dalam Mengantisipasi Penyebaran COVID-19: Laporan KKN Tematik COVID-19 2020. DEDIKASI: Community Service Reports, 2(2), 2328. https://doi.org/10.20961/dedikasi.v2i2.45881

Djono, D. (2020). Implementasi Adaptasi Baru melalui KKN UNS di Era Covid 19. DEDIKASI: Community Service Reports, 2(2), 9-22. https://doi.org/10.20961/dedikasi.v2i2.45927

Elpawati, E., Dara, S. D., \& Dasumiati, D. (2015). Optimalisasi Penggunaan Pupuk Kompos dengan Penambahan Effective Microorganism 10 (Em10) pada Produktivitas Tanaman Jagung (Zea mays L.). Al-Kauniyah: Jurnal Biologi, $8(2), 77-87$.

Estriyanto, Y. (2020). Penguatan Ketahanan Masyarakat terhadap Pandemi Covid19 dengan Program Kuliah Kerja Nyata. DEDIKASI: Community Service Reports, 2(2), 66-78. https://doi.org/10.20961/dedikasi.v2i2.46541

Hatta, P., Aristyagama, Y., Yuana, R., \& Yulisetiani, S. (2020). Active Learning Strategies in Synchronous Online Learning for Elementary School Students. Indonesian Journal of Informatics Education, 4(2).

Karuniawati, B., \& Putrianti, B. (2020). Gambaran perilaku hidup bersih dan sehat (phbs) dalam pencegahan penularan covid-19. Jurnal Kesehatan Karya Husada, 8(2), 34-53. 